\title{
The effect of Real Exchange Rate on Unemployment Evidence from Egypt
}

\author{
Dr. Eyad Mohammed Atya \\ Associate Professor of Economics \\ Economic Department, Zagazig University \\ Arab Republic of Egypt
}

\begin{abstract}
This paper aims to investigate the effect of real exchange rate on unemployment in the Egyptian economy during the period 1985-2015. There are three channels of effect real exchange rate on unemployment; these channels are macroeconomic channel, development channel, and labor intensity channel. We used three methods to estimate this relationship. They are Autoregressive Distributed Lag Model (ARDL), Fully Modified OLS (FMOLS), and Dynamic OLS (DOLS). The results reveal that real exchange has a positive and significant effect on unemployment. There is no significant effect of economic openness on unemployment. Furthermore, the correlation between unemployment and the growth is negative and significant. Also, the effect of labor productivity on unemployment was positive and significant. We can conclude the depreciation the real exchange rate will decrease the unemployment.
\end{abstract}

\section{Introduction}

There are three channels to transfer the effect of channels in real exchange rate to unemployment. These channels are macroeconomic channel, economic development channel, and employment intensity channel.

According to macroeconomic channel, there are two different mechanisms that transfer the effect of changes in exchange rate to unemployment rate through macroeconomic channel. One of these mechanisms has positive effect on unemployment, and another one has negative effects on unemployment.

The positive effect for macroeconomic channel occurs when depreciation of local currency encompasses an increase in the competitiveness which in turn leads to an increase in exports as well as decrease in imports due to an increase in the price of imported product. This reflects in an increase in demand for local products, this, therefore, induces the companies to hire more labor to face the increased demand on products which leads to a decreasing the unemployment rate and the opposite is true in case of currency appreciation (which means a decrease in the number of required units in order to obtain only one unit of dollars).

Unlike the previous mechanism which assumes that depreciation in the local currency has a positive effect on unemployment rate. Krugman and Taylor (1978) argued that a depreciation of local currency has negative effect on unemployment. Firstly, with this depreciation in local currency rate, there is an increase in

$$
\text { * تم استلام البحث في مايو 2017، وقبل للنشر في أغسطس } 2017 .
$$


exports and decrease in imports and this lead to increase the net exports. As local and foreign demand rising on local products, the prices of local products tend to be higher which lead to consequently lead to decrease a demand on them as well as production volume will be reduced. Secondly, income redistribution in response to devaluation of currency would be towards sectors which have a higher propensity to saving resulting in a decrease in investment, consumption and aggregate demand which in turn leads to decrease in demand on employment and this will lead to increase the unemployment. In other words, the effect of depreciation currency transferring to unemployment rate through total economy channel will differ overtime from a positive to negative effect.

For economic development channel, economic development channel is defined as a transfer the effect of local currency depreciation to unemployment rate through positive effect of local currency depreciation on economic growth and therefore, creating new jobs opportunities which then leads to a decline in unemployment rate (Frenkel, 2004). The effect of this channel is clear when the state adopts the production policy so as to import or produce which means an import substitution. So, this effect of depreciation of currency on unemployment rate won't be clear if the state adopts the policy of import substitution. However, this effect of depreciation will be similar to that of macroeconomic channel if the state follows the production strategy to achieve the exporting policy.

The third channel is employment intensity channel, this channel which transfers the effect of changes in real exchange rate to through changes intensity of production factors which used in production process. The effect of mechanism is obvious especially in developing countries because most of the capital goods and intermediate goods are imported. With depreciation of local currency which lead to increase in the price of imported goods including capital goods which used in the production process. The producers tend to use labor intensive production techniques and therefore, will make an increase on the employment demand a well as a decrease in unemployment rate and the opposite is true in case of currency appreciation (Frenkel, 2004).

To sum up, both of macroeconomic and economic development channels transfers the effect of changes of real exchange rate to the unemployment rate through change in production volume, while employmen intensity channel transfers this effect through changes in a combination of production factors used in the production process.

The structure of the paper organized as follow, section two presents the unemployment and real exchange rate in the Egyptian economy. Section three presents the literature review. Section four shows the methodology and econometric procedure and discussing the results, last part offers the conclusion and policy implications.

\section{Unemployment and Exchange Rate in Egypt}

In 1991, the Egyptian government began to implement the economic reform program; known as struc tural adjustment program, which is characterized by restructure the public sector, free prices, investment liberalization and foreign commerce policies and general budgetary deficit of the state. With the begging of implementing this program, the exchange rate for Egyptian pound dropped from 0.645 dollars in 1990 to 0.319 dollars in 1991 where value of Egyptian pound decreased by $50 \%$.

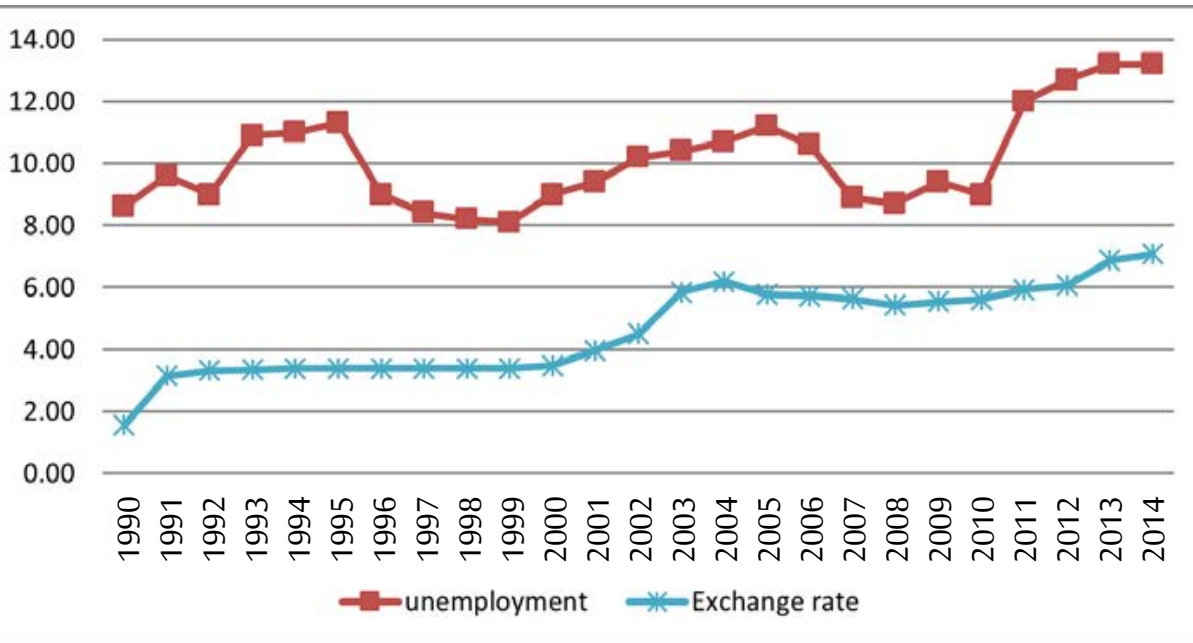

Source: World Bank

Figure (1): Unemployment and Exchange Rate in the Egyptian Economy

It is noticeable from figure (1) that during the period 1992-1999, the exchange rate of dollar has not significantly varied as it ranged from 3.322 Egyptian pounds in 1992 to 3.395 Egyptian pound in 1999. The stability of the Egyptian pound over this period is due to an increase in interest rate of the Egyptian pound to about four-to-five times than dollar interest rates as well as the intervention of the Egyptian central bank to protect the local currency.

Due to the inability of the Egyptian economy to achieve the required economic growth rates and large deficit in the trade balance, the Egyptian pound was depreciation to 3.86 Egyptian pounds for one dollar in July 2001 then was depreciated again to 4.15 pounds for one dollar in August 2001. However, during this period these measures didn't work appropriately to allay the concerns and risks of fluctuations despite the differences in interest rates on deposits between Egypt and the united states of America in favor of the Egyptian pound but this did not help to attract foreign capitals.

In the middle of January, 2002, the Egyptian pound was depreciation to 4.51 pounds per dollar with strong prospects to make new depreciation in Egyptian pound, also the dollar's price in the black market reached 5 pounds for one dollar. In addition, commodity exports were unable to cover half of what were imported. The exports amounted 6 billion dollars compared to 14 billion dollars for imports (Corporate Finance, 2003).

In January 29th, the flotation of the pound was declared as well as waiving the currency peg system which was used at the beginning of applying the financial liberalization program resulted in a depreciation of the Egyptian pound with $16 \%$ to reach 5.40 pounds per dollar.

The process of pound depreciation was continued to reach 6.30 pounds per dollar in 2006. With 25th January revolution in 2011, The Egyptian exchange rate was collapse to reach 7 pounds and jump to 7.15 in the end of 2011 after that it reached 7.60 pounds per dollar in 2013. Despite the considerable gulf support for the Egyptian economy to increase foreign currency reserves, the Egyptian pound also continued to depreciate compared to the American dollar which was due to economic problems that weakened the Egyptian economy.

In March 14th, 2016, the Egyptian Central bank depreciated the Egyptian pound by $14.30 \%$, where the Egyptian pound exchange rate reached 8.95 pounds for each dollar. The aim for this policy is to promote exports as well as increase the competitiveness of the Egyptian economy. 
In November 2016 the Egyptian central bank liberalized the dollar exchange rate to reach 13 pounds in banks as a reference price. The Egyptian central bank also released freedom for the working banks in Egypt to determine the price of foreign exchange rate as well as open their branches till nine o'clock and during public holidays to buy and sell the foreign currency and pay remittance of Egyptians working abroad. The central bank announced that there were no restrictions upon depositing and drawing processes of foreign currency for corporations or individuals. The aims of this measure have eased shortage in foreign currency, eliminated the parallel market and improve external accounts.

According to figure (1) we can see during the period 1990-1999, the changes in the unemployment rate weren't driven by exchange rate change however; it was stable during this period. The unemploymen rate varied greatly during this period as it increased from $8.6 \%$ in 1990 to $11.3 \%$ in 1995 then decreased to $8.1 \%$ in 1999. In other words, the changes in the unemployment rate weren't affected by the exchange rate during this period, because the exchange rate was stable.

During the period 2000-2005, the unemployment rate increased from 9\% in 2000 to $11.2 \%$ in 2005 which accompanied by a depreciation of the Egyptian pound as there is a negative relationship between unemployment rate and the value of Egyptian pound. During the period 2007-2008, there was fluctuated in the unemployment rate which encompassed by a decrease in dollar exchange rate from 5.635 pounds in 2007 to 5.433 pounds in 2008 and then increased to 5.545 pounds in 2009 .

Over the period 2010-2014, the unemployment rate significantly increased from 9\% in 2010 to $13 \%$ in 2014 which encompassed by a depreciation of the Egyptian pound. In other words, there was an inverse relationship between the value of the Egyptian pound and the unemployment rate; the lower the value of the Egyptian pound, the higher rate of the unemployment would be.

GARCH model was used to identify random error variance which represents fluctuation of exchange rates. Nominal variables, export and import growth rate according to their rate in dollars and nominal exchange rate, were relied upon as well as unemployment rate.

Figure (2) clarifies the range of fluctuation of unemployment rate, nominal exchange rate, exports and imports during the period 1992-2014.

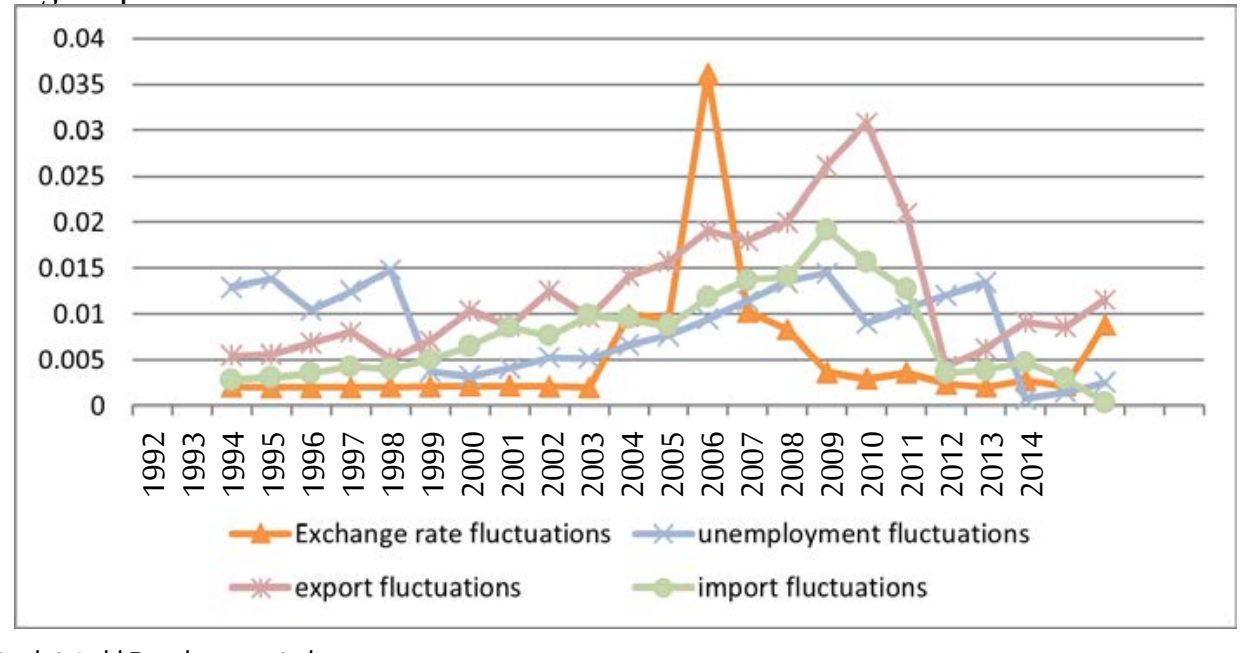

Source: World Bank, World Development Indicators

Figure (2): Fluctuations in Unemployment, Exchange Rate, Exports and Imports
Concerning fluctuation of unemployment and exchange rate, it is clear that fluctuation of exchange rate was insignificant during the period 1992-2003. The highest fluctuation in the exchange rate was during the year of 2006. However, there was higher fluctuation in the unemployment during the years 1995, 1998 2009 and 2013 which; therefore, fluctuation in the exchange rate did not affect fluctuation in the unemployment rate

Concerning fluctuations of unemployment rate and exports, it is obvious that fluctuations of exports reached its maximum rate during the year of 2010, which reflect an inverse relationship between fluctuations of unemployment rate and export fluctuations. For example, in 1998 when fluctuation rate of export decreased, the fluctuations rate of unemployment rate increased. In addition, in 2010, when export fluctuations rate increased, unemployment fluctuations rate decreased.

Concerning fluctuations of unemployment rate and imports, figure (2) shows that it is difficult to determine the relation between fluctuation of unemployment and fluctuation of imports. Sometimes, increasin the fluctuations of imports is coincided with an increase in fluctuations of unemployment rate as in 2009 Other times, increasing the fluctuations of imports is coincided with a decrease in fluctuations of unemployment rate as in 2013.

\section{Literature Review}

A number of studies have investigated the correlation between real exchange rate and unemployment which caused much controversy because they come up with different results concerning the nature of relationship between them. A group of studies found that there is a positive relationship between rea exchange rate and unemployment however other studies reached an inverse correlation between these two variables. These studies are surveyed as follows:

Frenkel and Ros (2006) investigated the effect of real exchange rate on unemployment rate in some Latin American countries such as Argentina, Brazil, Chile, and Mexico. This study concluded that there is a significant role of real exchange rate on unemployment rate.

Chang (2011) concluded a study to analysis the effect of uncertainty related to exchange rate on unemployment in South Korea and Taiwan in which the researcher used two different indicators of uncertainty of exchange rate. This study found that there is a long-term equilibrium correlation between unemploymen and uncertainty of exchange rate in South Korea and Taiwan. In addition, it was concluded that uncertainty of exchange rate lead to a short- term effect on unemployment and vice versa.

Nyahokwe and Ncwadi (2013) studied the effect of real exchange rate fluctuations on unemployment in South Africa during the period 2000-2010. This study used the Co-integration and vector auto-regression (VAR) and the GARCH model. In addition, this study used real exchange rate, exports, real interest rate and gross domestic product (GDP) as explanatory or independent variables and unemployment rate as dependent variable. In this study, it is concluded that there is a long-term correlation among these variables. These results also indicated that the real exchange rate has a significant effect on unemployment rate as it is one of the other determinants as well as clarifies most changes happened in the unemployment rate. 
Amar (2003) investigated the effect of exchange rate on gross domestic product (GDP) in the Egyptian economy, particularly the effect of depreciation of Egyptian pound on GDP as well as some other economic variables during the period 1964-2000. This study concluded that there is an inverse correlation between real exchange rate and GDP; the higher the rate of real exchange rate (depreciation of the Egyptian pound) is, the greater the contracting effect would be on the GDP. However, the statistical correlation between these two variables was weak.

Shaari et al. (2013) analyzed the effect of oil prices and exchange rate on unemployment in Malysia using monthly data during the period 2009-2011. The study employs the Johansen VAR - based Co-integration. The study found that there is a long relationship among exchange rate, oil price, and unemployment rate. Also the results indicated the exchange rate has a short-term effect on unemployment while the oil price does not affect the unemployment.

Chimanani et al. (2012) investigated the effect of exchange rate on unemployment rate using pane data during the period 1995-2005 in ten countries such as Pakistan, India, Bangladesh, Japan, Brazil, Algeria Argentina, Sri Lank, and Colombia. This study employed Ordinary Least Squares (OLS). The results indicated real exchange rate has significant effect on unemployment rate.

Feldmann (2011) used data from 17 industrial countries during the period of 1982-2003 to investigate the effect of exchange rate fluctuations on unemployment. It was concluded that the increase of exchange rate fluctuations leads to increase in unemployment rate, but the effect is small.

Ratha (2010) investigated the effect of currency depreciation on the Indian economy. The results indicated that currency devaluation has contracting effects in the short term and it has expanding effects in the long-term. In other words, it has a positive effect on GDP of the Indian economy

Mcpherson (2000) investigated the correlation between exchange rate and economic growth in Kenya during the period 1970-1996. This study concluded that the relationship between real exchange rate and economic growth is not clear in Kenya; however, it may be an indirect one. This is clear through different channels such as investment, imports, agricultural production and foreign aids as the real exchange rate effects on these variables of which are of GDP variables.

Kandil et al. (2007) discussed the effects of fluctuations of exchange rate on the economic activity in Turkey. This study found that the exchange rate has opposite effects on economic growth and investmen and exports. It also highlighted that the unexpected effects of depreciation the currency have expanded effects on GDP while expected devaluation of the currency has contracting effects on GDP.

Ayen (2014) discussed the effect of currency depreciation on GDP in Eithiopia during the period 19982010. It was concluded that currency devaluation has a contracting effect on GDP on the long-term and natural effect on the short-term. The results also indicated that the monetary policy has a positive effect on GDP; however the governmental expenditure has a negative effect on it. This study found that the Ethiopian government doesn't allow for supply and demand forces to determine the value of Ethiopian currency but it intervenes in the market to achieve stability. In addition, this study significantly recommended the importance and positive effect of monetary policy on GDP.

\section{Econometric Analysis}

\section{Model and Data}

To analysis the effect of exchange rate on unemployment in the Egyptian economy, we use time series data during the period 1985-2015 and use the following model.

unem $=\beta_{0}+\beta_{1}$ exchange $+\beta_{2}$ openn $+\beta_{3}$ growth $+\beta_{4}$ product $+\mu$

Table (1) shows the name of the variable and the source of data.

Table (1): the Variables used in the Analysis

\begin{tabular}{lll}
\hline & Symbol Name & Source \\
\hline Unem & Unemployment & \multirow{W}{*}{ World Bank: } \\
\hline Exchange & Real exchange rate & \\
\hline Open & Economic openness & World Development Indicators \\
\hline Growth & GDP per capita (constant 2010 u\$) & \\
\hline product & Labor productivity &
\end{tabular}

\section{Econometric Procedures}

We start by testing the stationarity in the data. We apply two kinds of test. They are Augmnted Dickeyfuller (ADF) test (Dickey and Fuller; 1979, 1981) and Phillips Perron (PP) test (Phillips and Perron; 1988). Table (2) presents the results of Augmented Dickey -Fuller (ADF) test and Phillips Perron (PP). The results indicate. Table (2) : Augmented Dickey-fuller and Pillip-Perron Tes

\begin{tabular}{|c|c|c|c|c|c|c|}
\hline \multirow{2}{*}{ Variable } & \multicolumn{3}{|c|}{ ADF } & \multicolumn{3}{|c|}{ PP } \\
\hline & Intercept & Intercept and trend & None & Intercept & Intercept and trend & None \\
\hline unem & $\begin{array}{c}-1.2466 \\
(0.638)\end{array}$ & $\begin{array}{l}-1.7436 \\
(0.701)\end{array}$ & $\begin{array}{l}0.6953 \\
(0.859) \\
\end{array}$ & $\begin{array}{c}-1.5606 \\
(0.487) \\
\end{array}$ & $\begin{array}{l}-2.0479 \\
(0.548)\end{array}$ & $\begin{array}{l}0.6028 \\
(0.839) \\
\end{array}$ \\
\hline $\mathrm{D}$ (unem) & $\begin{array}{c}-4.4863 \\
(0.002)^{* * *}\end{array}$ & & & $\begin{array}{l}-4.4896 \\
(0.002)^{* * *}\end{array}$ & & \\
\hline Exchange & $\begin{array}{l}-1.8482 \\
(0.349) \\
\end{array}$ & $\begin{array}{l}-2.8084 \\
(0.207) \\
\end{array}$ & $\begin{array}{l}-1.7019 \\
(0.084)^{*}\end{array}$ & $\begin{array}{c}-1.5632 \\
(0.486) \\
\end{array}$ & $\begin{array}{l}-2.7761 \\
(0.218)\end{array}$ & $\begin{array}{l}-1.8376 \\
(0.064)^{*}\end{array}$ \\
\hline D(Exchan) & $\begin{array}{c}-6.5651 \\
(0.000)^{* * *} \\
\end{array}$ & & & $\begin{array}{l}-6.6477 \\
(0.000) * * * \\
\end{array}$ & & \\
\hline Open & $\begin{array}{l}-2.7016 \\
(0.089)^{*}\end{array}$ & $\begin{array}{l}-2.6051 \\
(0.281) \\
\end{array}$ & $\begin{array}{r}-1.3038 \\
(0.172) \\
\end{array}$ & $\begin{array}{c}-1.38911 \\
(0.571) \\
\end{array}$ & $\begin{array}{l}-1.4961 \\
(0.804) \\
\end{array}$ & $\begin{array}{r}-0.7857 \\
(0.366) \\
\end{array}$ \\
\hline $\mathrm{D}$ (Open) & $\begin{array}{c}-3.9778 \\
(0.006)^{* * *}\end{array}$ & & & $\begin{array}{c}-3.9776 \\
(0.006)^{* * *} \\
\end{array}$ & & \\
\hline Growth & $\begin{array}{l}0.6303 \\
(0.987) \\
\end{array}$ & $\begin{array}{l}-4.2704 \\
(0.014)^{* *}\end{array}$ & & $\begin{array}{l}-0.1269 \\
(0.936) \\
\end{array}$ & $\begin{array}{l}-2.3031 \\
(0.417) \\
\end{array}$ & $\begin{array}{l}3.6348 \\
(0.999) \\
\end{array}$ \\
\hline D(Growth) & & & & $\begin{array}{l}-2.7372 \\
(0.083)^{*}\end{array}$ & $\begin{array}{r}-2.6367 \\
(0.269) \\
\end{array}$ & $\begin{array}{r}-1.3254 \\
(0.166) \\
\end{array}$ \\
\hline Product & $\begin{array}{l}-0.2840 \\
(0.914) \\
\end{array}$ & $\begin{array}{c}-2.4769 \\
(0.335) \\
\end{array}$ & $\begin{array}{l}5.4572 \\
(1.000)\end{array}$ & $\begin{array}{l}-0.2840 \\
(0.914) \\
\end{array}$ & $\begin{array}{l}-2.5369 \\
(0.309)\end{array}$ & $\begin{array}{l}5.4572 \\
(1.000) \\
\end{array}$ \\
\hline $\mathrm{D}$ (Product) & $\begin{array}{c}-5.2177 \\
(0.000)^{* * *} \\
\end{array}$ & & & $\begin{array}{l}-5.2177 \\
(0.000)^{* * *} \\
\end{array}$ & & \\
\hline Critical Values & & Level & & & First difference & \\
\hline$\% 1$ & -3.8315 & -4.5326 & -2.6998 & -3.8574 & -4.5716 & -2.6998 \\
\hline$\% 5$ & -3.0299 & -3.6736 & -1.9614 & -3.0404 & -3.6908 & -1.9614 \\
\hline \%10 & -2.6552 & -3.2774 & -1.6066 & -2.6606 & -3.2869 & -1.6066 \\
\hline
\end{tabular}


We can see from table (2), ADF and PP indicate that variables Unem, Exchange, Open, and Product are not stationarity at level but become stationarity at first difference, this means that they are integrated I(1) at $1 \%$ of significant.

For the Growth variable, the both test for unit root give different result, ADF test show that Growth variable is not stationarity at level, while PP test shows that Growth variable is not stationarity at level or first difference. So will employ additional unit root test to determine the stationarty of this variable. We employ (DF-GLS) Dickey-Fuller GLS (ERS). Table (3) shows the result of this test. The result indicate that Growth variable is stationarty at first difference.

Table (3): Dickey-Fuller GLS unit root test

\begin{tabular}{lccc}
\hline DF-GLS (ERS) & & Intercept & Intercept and trend \\
\hline & & -0.6342 & -2.8900 \\
\hline Growth & & -2.2075 & \\
\hline D(Growth) & $1 \%$ & -2.6501 & -3.7700 \\
\hline Critical Values & $5 \%$ & -1.9534 & -3.1900 \\
& $10 \%$ & -1.6098 & -2.8900 \\
\cline { 2 - 4 } & &
\end{tabular}

The second step is testing the existence long the long relationship among the variables, we employ Autoregressive distributed lag model (ARDL) to test the co-integration using Unrestricted Error Correction Model (UECM).

\section{Table (4): Bounds test}

\begin{tabular}{|c|c|c|c|c|c|c|c|}
\hline \multirow[t]{2}{*}{ Models } & \multicolumn{5}{|c|}{ Regressors: } & \multirow{2}{*}{$\frac{K}{4}$} & \multirow{2}{*}{$\begin{array}{l}\text { F-statistic } \\
11.496^{* * *} \\
\end{array}$} \\
\hline & Unem & Open, $G$ & Produc & $(3,2,3,1,3)$ & SIC & & \\
\hline \multirow{7}{*}{$\begin{array}{l}\text { Significant } \\
\text { level }\end{array}$} & \multicolumn{7}{|c|}{ Critical values bounds } \\
\hline & \multicolumn{3}{|c|}{ Lower Critical Bounds (10) } & \multicolumn{4}{|c|}{ Upper Critical Bounds (I1) } \\
\hline & & (1) & (2) & (1) & (2) & (3) & (4) \\
\hline & $10 \%$ & 2.72 & 2.45 & 3.77 & 3.52 & 3.35 & 3.23 \\
\hline & $5 \%$ & 3.23 & 2.86 & 4.35 & 4.01 & 3.79 & 3.61 \\
\hline & $2.5 \%$ & 3.69 & 3.25 & 4.89 & 4.49 & 4.18 & 3.99 \\
\hline & $1 \%$ & 4.29 & 3.74 & 5.61 & 5.06 & 4.68 & 4.43 \\
\hline
\end{tabular}

From Table (4) we can find that calculated F-statistics is bigger than the upper critical Bounds, so we do not accept the null hypothesis of no cointegration which means that there is long relationship among the variables, in other words there is cointegration at $1 \%$ level of significant. So we proceed to estimate the coefficient of the model.

We retest the cointegration using Johansen test to make sure that there is a long run correlation among the variable table (5) show the result of Johansen test. The results indicate that there is long run relationship
Table (5): Johansen Cointegration Test

\begin{tabular}{lcc}
\hline & trace & Eigenvalue \\
\hline None & 0.762240 & 0.762240 \\
& 69.819 & 33.877 \\
& $(0.003)^{*}$ & $(0.042)^{*}$ \\
\hline At most 1 & 0.668231 & 0.668231 \\
& 47.856 & 27.584 \\
& $(0.037)^{*}$ & $(0.069)$ \\
\hline At most 2 & 0.464026 & 0.464026 \\
& 29.797 & 21.132 \\
& $(0.262)$ & $(0.291)$ \\
\hline At most 3 & 0.265630 & 0.265630 \\
& 15.495 & 14.265 \\
& $(0.496)$ & $(0.442)$ \\
\hline At most 4 & 0.012832 & 0.012832 \\
& 3.8415 & 3.8415 \\
& $(0.578)$ & $(0.578)$ \\
\hline & 1 & 1 \\
& Cointegrating & Cointegrating \\
\hline
\end{tabular}

After we confirm that there is a long correlation among the variables, we proceed to estimate the model using three methods. These methods are Dynamics Ordinary Least Squares (DOLS), Fully Modified Ordinary Least Squares (FMOLS), and Autoregressive Distributed Lag Model (ARDL). Table (6) presents the results of these methods.

\section{Table (6) Estimate the Model by ARDL, FMOL and DOLS}

\begin{tabular}{llll}
\hline Variables & ARDL & FMOLS & DOLS \\
\hline Exchange & 15.814 & 7.7504 & 12.173 \\
& $(5.188)^{* * *}$ & $(1.767)^{*}$ & $(1.778)$ \\
\hline Open & 0.0361 & 0.0014 & 0.1119 \\
& $(1.073)$ & $(0.026)$ & $(1.591)$ \\
\hline \multirow{2}{*}{ Growth } & -0.0145 & -0.0162 & -0.0265 \\
& $(-2.771)^{* *}$ & $(-1.912)^{*}$ & $(-2.737)^{* *}$ \\
\hline Product & 0.0017 & 0.0018 & 0.0028 \\
& $(3.796)^{* * *}$ & $(2.441)^{* *}$ & $3.204)^{* * *}$ \\
\hline Const & -14.263 & -11.960 & -22.622 \\
& $(-3.573)^{* *}$ & $(-1.692)$ & $(-2.804)^{* *}$ \\
\hline ECM(-1) & -1.4422 & & \\
& $(-5.765)^{* * *}$ & & \\
\hline
\end{tabular}

$(*),(* *)$ and $(* *)$ indicate $10 \%, 5 \%$ and $1 \%$ level of significant, respectively.

We can observe that effect of real exchange rate on unemployment is positive and significant in ARDL and FMOLS, but not significant in DOLS. Appreciation of real exchange rate will increase the unemployment and depreciation of the real exchange rate will reduce the unemployment. The result agree with the literature for example Revenga (1992), Burgess and Knetter (1998), Campa and Goldberg (2001),and Frenkel (2004). One percent depreciation in the real exchange rate will lead to a $15.8 \%$ and $7.75 \%$ decrease in the unemployment according to ARDL and FMOLS respectively. 
For the relation between economic openness and unemployment, we can see there is a positive relation in all methods between economic openness and unemployment, but this relationship is not significant. This means that foreign sector does not affect unemployment, because the role of foreign sector is not significant in the Egyptian economy.

For the correlation between growth and unemployment, the results indicate that the relationship between growth and unemployment is negative and this relationship is significant in the three estimation methods. This result agrees with the literature see for example Frenkel (2005). The results reveal that an increase in economic growth will lead to decrease in unemployment. Because the improving the economic growth will create new jobs.

For the relationship between labour productivity and unemployment, there is a positive relationship between labour productivity and unemployment, the effect of the labour productivity on unemployment is positive and significant in all estimation methods. This means that higher labor productivity lead to reduce the employment which they use in the production process. The Egyptian economy can use this through increasing the investment and open new projects.

\section{Conclusion}

The aim of this paper is to investigate the effect of real exchange rate on unemployment in the Egyptian economy during the period 1985-2015. We used three methods to estimate the effect of real exchange rate on unemployment. These methods are Autoregressive Distributed Lag Model (ARDL), Fully Modified OLS (FMOLS), and Dynamics OLS (DOLS).

The real exchange rate affects unemployment through three channels: macroeconomic channel, development channel and labor intensity channel.

According to these channels, the results found that depreciation of real exchange rate leads to decrease the unemployment in the Egyptian economy, because the depreciation of real exchange rate wil increase exports and gross domestic product, this is according the macroeconomic channel. According to development channel, depreciation of real exchange rate leads to decrease unemployment through offer new jobs. According to labor intensity channel, a depreciation in the real exchange rate leads to increase in relative price of imported capital goods against the price of labor which makes the companies to switch from imported capital goods and this lead to increase the unemployment.

The result found that there is a negative and significant relationship between economic growth and unemployment. For labor productivity, the results reveal that effect of labor productivity on unemployment is positive and significant. For economic openness, there is no significant effect for economic openness on unemployment.

For policy implications, the Egyptian government can try to solve the unemployment problem through encourage the investors to build new projects to direct the production to exports which is powered by depreciation of real exchange rate. Moreover, improving the economic growth and increasing the labor productivity will reduce the unemployment.

\section{References:}

- Amar, S., (2003). The effects of exchange rate on gross domestic product in the Egyptian economy. Faculty of Economic and Political Science, Cairo university. (In Arabic)

Ayen, Y., (2014). The effects of currency devaluation on output: the case of Ethiopian Economy, Journal of economics and international finance, Jimma University, PP. 1-9.

- Burgess, S. M. and Knetter. M. M., (1998). An international Comparison of Employment Audjustment to Exchange Rate Fluctuations. Review of International Economics, Blackwell Publishing, Vol. 6(1), PP.151-63.

- Chinmanani, H., Bhutto, N.A.,Butt, F.,Sheikh, S. A., and Devi, W., (2012). The effect of exchange rate on unemployment rate in Asian countries. Proceedings of 2nd International Conference on Business Management.

- Change, S. C., (2011). The interrelationship between exchange-rate uncertainty and unemployment for South Korea and Taiwan: Evidence from a vector autoregressive approach. International Economics, 125, 65-82.

- Dickey, D. A. and Fuller, W. A., (1979). Distribution of Estimators of Autoregressive Time Series with a Unit Root. Journal of the American Statistical Association, 74, 427-31.

- Feldmann, H., (2011). The unemployment effect of exchange rate volatility in industrial countries. Economic Letters, 111(3), 268-271.

- Frenkel, R., (2004). Real Exchange Rate and Employment in Argentina, Brazil, Chile and Mexico

- Frenkel, R., and Ros, J., (2006). Unemployment and real exchange rate in Latin America. World Development, 34(4), 631-646.

- Goldberg, L., Tracy, J., and Aronson, S,(1999). Exchange rate and unemployment instability: Evidence from matched CPS data. American Economic Review. Paper and Proceeding, Vol. 89 No.2 PP. 204-210

- Johansen, S., (1995). Likelihood Based Inference in Cointegrated Vector Auto-regressive Models, Oxford: Oxford University Press.

- Kandil, M.,Berument, H. and Dincer. N, (2007). The effects of exchange rate fluctuations on economic activity in Turkey. Journal of Asian Economics 18, 466-489

Klein, Michael W., Scott Schuh and Robert K. Triest, (2002). Job Creation, Job Destruction, and the real exchange rate. NBER Working Papers 7466

Krugman, P. and Taylor, L., (1978). Contractionary effects of devaluation, Journal of International Economics, (8), PP.445-56

Mcpherson, M., (2000). Exchange Rate and Economic growth in Kenya: An Econometrics Analysis, African Economic Policy. PP.8-9.

- Nyahokwe, O., and Ncwadi, R., (2013). Impact of exchange rate volatility on unemployment in South Africa. Mediterranean Journal of Social Science, 4(3), 109-120.

- Phillips, P. C.B. and Perron, P., (1988). Testing for a Unit Root in Time Series Regression. Biometrika, 75(2), 335-46. 
- Shaari, M.S., Hussain, N. E., and Abdul Rahim, H., (2013). The effects of oil price changes and exchange rate volatility on unemployment: Evidence from Malaysia. International Journal of Research in Business and Social Science, IJRBS, 2(4), 72-83.

- $\quad$ Ratha, H., (2010). does devaluation work for India? Economic Bulletin, 30 (1) PP.247-264

- Revenga, A. L., (1992). Exporting jobs? The Impact of Import Competition on Employment and Wages in US Manufacturing. Quarterly Journal of Economics, 107 (1), PP. 255-284. 